\title{
Emerging Adulthood - an Easy Time of Being? Meaning in Life and Satisfaction with Life in the Time of Emerging Adulthood
}

\author{
Veronika Kohútová (iD, Marián Špajdel iD, Mária Dědová i \\ Department of Psychology, Faculty of Philosophy and Arts, University of Trnava, Hornopotočná 23, 91843 Trnava, \\ Slovak Republic
}

\begin{abstract}
Personality seems to be a stable predictor of satisfaction with life and meaning in life. The effects of emerging adulthood are currently under-explored. The aim of the present study is to explore whether the characteristics of emerging adulthood explain additional variance in satisfaction with life and meaning in life that is not explained by the Big Five factors. The sample involved 244 Slovak university students (13.1\% men), who completed the Satisfaction with Life Scale, Meaning in Life Questionnaire, Big Five Inventory-2 and the Questionnaire of Emerging Adulthood characteristics. The results of linear hierarchical regression analyses, controlling for age and gender, showed that emerging adulthood characteristics added $6.4 \%$ of the explained variance in satisfaction with life, $28.1 \%$ of the explained variance in presence of meaning and $17.1 \%$ of the explained variance in search for meaning. The current study shows that the emerging adulthood characteristics are important for satisfaction with life and meaning in life.
\end{abstract}

Key words: emerging adulthood, Big Five personality traits, meaning in life, satisfaction with life

\section{Introduction}

Young university students go through several significant changes. The sociocultural changes in the last decades have created conditions for the establishment of a new specific developmental stage - emerging adulthood (Arnett, 2001, 2004), occurring predominantly in young people continuing to study at the university (Côte, 2014). These sociocultural changes have delayed and complicated taking on adult social roles, such as a full-time job, partner, marriage, parenthood, and, on the other hand, have led to remaining financially and residentially dependent on parents for longer time, as full independence is not achieved in other life areas (Arnett, 2001; Piotrowski et al., 2018). This delay is not only characteristic for the United States and Western countries, but also for the rest of Europe, the Czech Republic (Macek et al., 2007) and

Correspondence concerning this article should be addressed to Veronika Kohútová, Department of Psychology, Faculty of Philosophy and Arts, University of Trnava, Hornopotočná 23, 91843 Trnava, Slovak Republic.

E-mail: kohutova.veronka@gmail.com

Received October 27, 2020

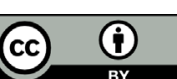


Slovakia (Šprocha, 2018; Kohútová \& Dědová, 2019) among others. To our knowledge, the characteristics of emerging adulthood have not yet been investigated in Slovakia. Emerging adulthood in Slovakia is manifested by postponed marriages and parenthood (Džambazovič, 2018; Statistical Office of the SR, 2021) and by the lack of adulthood feeling that is present in the majority of Slovak students (Roupa, 2016).

Arnett (2004) characterized emerging adulthood by instability, identity exploration, a great number of possibilities, self-focused orientation and feeling of being between adolescence and adulthood. These characteristics were confirmed in various other countries (e.g., Macek et al., 2007, Oleskowitz \& Misztela, 2015; Crocetti et al., 2015), even though they partially differ from one another (Pace et al., 2016). The differences were found even across gender. Girls tend to report significantly higher level in these characteristics (Sirsch et al., 2009), mainly in experimentation and self-focus (Negru et al., 2012; Reifman et al., 2007). While experimentation and possibilities appear as a great and optimistic time for young people (Arnett, 2000), the prolonged time of experimentation together with many possibilities and uncertainty about the right way to live (Schwartz et al., 2016) might cause emotional problems (Lane et al., 2017) and affect the level of life satisfaction (Karaś et al., 2014). In addition, the prolonged identity moratorium characterized by experimentation goes along with the development of meaning in life (Hill et al., 2016).

Meaning in life, as one of the indicators of the eudaimonic concept of well-being (Ryff \& Singer, 1998; Samman, 2007), and satisfaction with life, as an indicator of hedonistic well-being concept (Diener et al., 1999), are essential for healthy life and optimal human functioning. Meaning in life, defined as the main life motivation, is related to personal goals and beliefs reflecting individuals' life attitudes (Park, 2010). Individuals feel the presence of meaning in life when they have found their place in the world and the goal of their lives. In addition, they may continue to search for meaning even when meaning is present in their lives (Steger et al., 2008). Meaning in life is not the final goal, but rather a lifelong process of searching and finding. Even though the presence and search for the meaning may be parallel, Steger et al. (2008) found a negative correlation between them, and this relationship differs among people with greater openness and approach orientation.

Human meaning in life plays an important role in subjective well-being (SWB) (García-Alandete, 2015). The satisfaction with life as a part of SWB reflects cognitive evaluation of life as a whole (Ryan \& Deci, 2001). It is a relatively stable construct. A change can occur for some time after a significant life event, with a tendency to return to the original level (Quevedo \& Abella, 2011). This stability suggests that its level is predicted by personality. In case of the Big five personality traits, satisfaction with life is linked with extraversion, negative emotionality, and conscientiousness (Tanksale, 2015; Morris et al., 2015). Tanksale (2015) found that the Big Five traits predicted $17 \%$ of the variance in satisfaction with life. This was confirmed by Kohút, Kohútová, Žitný et al. (2020), who found that the Big Five personality traits measured after 6 months predicted $20 \%$ of the variance in satisfaction with life.

Similarly to satisfaction with life, it is probable that people have their predispositions for certain levels of meaningfulness. Schnell and Becker (2006) found that personality factors explained $16 \%$ of variance in meaningfulness; however, the source of meaning is important for this relationship. Meaning in life is linked with extraversion, neuroticism (Francis \& Hills, 2008), and conscientiousness (Halama, 2005). 
Certain facets of openness to experience and agreeableness were in a relationship with search for meaning and certain facets of extraversion, agreeableness, conscientiousness, and neuroticism correlated with the presence of meaning (Steger et al., 2006). These relationships suggest a possible prediction by personality not just for satisfaction with life but also for meaning in life.

Even though personality appears to be important for both satisfaction in life and meaning in life, research suggests that the characteristics of emerging adulthood time might also be linked to them. Negru (2012) found that satisfaction with life was positively predicted by exploration, possibilities, self-focus as well as interaction with others and negatively by instability. Similarly, according to Smojver-Ažić et al. (2017), the dimensions of emerging adulthood together predict the level of satisfaction with life. Perception of life as a time of possibilities, self-focus, and less as a time of instability and identity exploration predicts a higher level of satisfaction with life. So far, we did not find any research that directly focused on the relation between emerging adulthood time and meaning in life. However, a study concerning meaning in life throughout life found that the level of presence of meaning in life was at the lowest and search for meaning was at the highest level at the beginning of adulthood (Steger et al., 2009). In a qualitative study concerning emerging adulthood's conceptions of meaning, Glanzer et al. (2015) found that one-third of respondents did not know their life purpose. As stated above, emerging adulthood is the time for individuals to explore and consider who they are and what they want in their lives. The prolonged identity exploration (Wood et al., 2018) is manifested by exploring new things, opportunities, relationships, future career, and values. Identity exploration and searching for meaning in life are similar constructs, but they are not even (Dezutter et al., 2014). Identity relates to daily decisions and searching for "who I am", while the meaning in life focuses on long-lasting goals and life direction (Sumner et al., 2014). However, their development is mutually supported (Hill et al., 2016). Time of identity exploration in emerging adulthood creates an ideal time to search for and find meaning in life.

The above-mentioned relations of emerging adulthood characteristics to satisfaction with life and meaning in life suggest that, in addition to personality traits, the dimensions of emerging adulthood may be important for meaning in life and satisfaction with life. A prolonged time of identity exploration and experimentation with different options might be the time of opportunities, but it might also cause uncertainty influencing life satisfaction and meaning in life. Our study brings insight into which psychological characteristics are crucial for meaning in life and life satisfaction in emerging adulthood. The main aims of the present study are 1) to confirm that meaning in life and satisfaction with life can be explained by the Big Five personality traits and 2) to explore, whether the dimensions of emerging adulthood explain additional variance in the Slovak university student sample. It was hypothesized that Big Five personality traits would explain variance in Satisfaction with life and the Presence of meaning. It was expected that dimensions of emerging adulthood would explain the added variance over BFI-2 in satisfaction with life and presence of meaning.

\section{Methods}

\section{Sample}

A total of 244 Slovak university students participated in the study, $86.9 \%$ women and $13.1 \%$ men, with the mean age of 21.36 
years $(S D=2.54)$. Of the participants, $75.4 \%$ attended bachelor's studies, $21.7 \%$ attended master's studies, and $2.9 \%$ studied for a doctoral degree. Almost half of the participants $(45.5 \%)$ were single, $7 \%$ was in a short-term relationship, $40.6 \%$ in a long-term relationship; $3.3 \%$ were engaged and $3.7 \%$ were married.

\section{Measures}

Presence of and search for meaning were measured by the Meaning in Life Questionnaire, (MLQ, Steger et al., 2006) consisting of a 10-item scale with 5 items for each dimension. The presence of meaning measures the level of life fulfilment. Search for meaning in life aims to determine the level of motivation and effort invested in searching for or deepening of life meaning. The measure is rated on a 7-point Likert scale (1 - Absolutely untrue; 7 Absolutely true). A higher score means a higher level of presence and search for meaning. The Slovak translation was obtained from the authors. The translation is available on http:// www.michaelfsteger.com/?page id=13. The authors are not listed.

Global cognitive evaluation of life was measured by Satisfaction with Life Scale (SWLS, Diener et al., 1985), which consists of 5 items rated on the 7-point Likert scale (1 - Strongly disagree; 7 - Strongly agree). The Slovak version was obtained by 2 translations and one back-translation. A higher score means higher life satisfaction.

Dimensions of emerging adulthood defined by Arnett (2001) were measured by a questionnaire created by Macek et al. (2007). The questionnaire is inspired by the original Inventory of the Dimensions of Emerging Adulthood (Reifman et al., 2007). It was translated from Czech by 2 independent translations and then translated back to Czech. The questionnaire consists of 29 items, which are rated on a 4-point Likert scale ( 1 - Strongly disagree; 4 -Strongly agree). It comprises 6 dimensions - Stability (6 items), Self-focused orientation (7 items), Diffuse orientation (6 items), Clarity of values (5 items), Identity exploration (3 items), Concerns for others (2 items).

Slovak version of the Big Five Inventory-2 (BFI-2) (Soto \& John 2017) adapted and validated in Slovakia by Halama et al. (2020) and Kohút et al. (2020) was used to measure the Big Five traits. It consists of 60 items rated on a 5-point Likert scale ( 1 - Strongly disagree; 5 - Strongly agree), focusing on 5 dimensions - Emotional stability, Extraversion, Open-mindedness, Agreeableness, and Conscientiousness, 12 items for each dimension.

The demographic data were added to the questionnaires, focusing on age, sex, partnership status, and the university degree being pursued.

\section{Procedures and Analyses}

To collect the data, Slovak university students from 18 to 29 years old, were approached to participate in the research. The questionnaires were distributed online through online social networks of students from different Slovak universities. By using a snowball sampling technique, the participants from a broad range of study fields were recruited. The participants had to fulfil the requirements of being Slovak, currently studying at a university and be 18 to 29 years old. All participants signed an informal consent before filling out the questionnaires. Ethical approval was not required. The study was carried out in accordance with the APA Ethical Guidelines.

Before data collection we did not calculate the minimum sample size for our analysis. Data were processed and analyses were carried out using Jamovi (2020). Cronbach's alpha values were calculated for satisfaction with life, presence of meaning, search for 
meaning, all factors of $\mathrm{BFI}-2$, and all factors of the dimensions of emerging adulthood to assess the reliability of the scales in the current data set (Table 1). Simple bivariate analyses (Pearson $r$ ) were calculated to assess the strength and significance of relationships between predictors and outcome variables.

The hierarchical linear regression was used to evaluate the hypotheses of Big Five personality traits and emerging adulthood dimensions predicting the meaning in life and satisfaction with life. The regression analyses were done separately for presence of meaning in life, search for meaning in life and life satisfaction. All regression analyses were controlled for age, gender, educational level and relationship status (in/ without relationship) (block 1). In the second block, all domains of the $\mathrm{BFI}-2$ (extraversion, agreeableness, conscientiousness, negative emotionality and open-mindedness) were added to the model. In the third block, all dimensions of emerging adulthood (stability, self-focused orientation, diffuse orientation, clarity of values, identity exploration, concerns for others) were added. The final models were checked and they passed the assumptions of linear regression, e.g. non-significant Durbin-Watson statistics, variance inflation factor values lower than 4 (Pan \& Jackson, 2008) and tolerance values higher than 0.25 (Huber \& Stephens, 1993). Based on the results of the final models, using G*power (Faul et al., 2009), we calculated posthoc power analysis, which showed that the achieved power exceeded the 0.99 level.

Table 1 Mean, SD, Cronbach's $\alpha$ of examined variables

\begin{tabular}{lcccc}
\hline & $N$ & Mean & $S D$ & Cronbach's $\alpha$ \\
\hline Satisfaction with life & 243 & 22.40 & 6.10 & 0.83 \\
Presence of meaning & 244 & 24.40 & 7.11 & 0.91 \\
$\quad$ Search for meaning & 242 & 26.00 & 5.28 & 0.73 \\
Emerging adulthood & & & & \\
$\quad$ Stability & 244 & 15.70 & 3.69 & 0.83 \\
Self-focused orientation & 243 & 13.50 & 3.86 & 0.80 \\
Diffuse orientation & 244 & 10.20 & 2.54 & 0.71 \\
Clarity of values & 242 & 15.00 & 3.09 & 0.84 \\
Identity exploration & 241 & 9.14 & 2.10 & 0.78 \\
Concerns for others & 243 & 6.10 & 1.19 & 0.48 \\
Big Five & & & & \\
Extraversion & 243 & 3.28 & 0.69 & 0.83 \\
Agreeableness & 243 & 3.90 & 0.53 & 0.79 \\
Conscientiousness & 243 & 3.61 & 0.68 & 0.87 \\
Negative emotionality & 243 & 3.13 & 0.86 & 0.91 \\
$\quad$ Open-mindedness & 243 & 3.82 & 0.71 & 0.72 \\
\hline
\end{tabular}

Note. The table shows descriptive information about outcome variables, variables of emerging adulthood and variables of Big Five inventory. $N$ - number of participants vary among variables because of insufficient completion of the questionnaires. 


\section{Results}

Table 1 shows the mean, SD and Cronbach's $\alpha$ for all predictors and outcome variables used in this study.

First, the study focused on the correlations between predictors - factors of $\mathrm{BFI}-2$ and factors of dimensions of emerging adulthood with outcome variables - satisfaction with life, presence of meaning and search for meaning. Satisfaction with life correlated significantly with all variables of emerging adulthood characteristics but concerns for others and by all domains of Big Five but open-mindedness. The strongest positive correlations were found with stability and clarity of values, and the strongest negative correlation with negative emotionality. Similarly, the presence of meaning correlated with all variables of emerging adulthood but concerns for others, and by all domains of Big Five. The strongest positive relationships were found with clarity of values and stability. Negative relationships were found with identity exploration and negative emotionality. Meaning in life significantly correlated positively with identity exploration and negative emotionality and negatively with stability. The results are shown in Table 2. The correlation matrix of all examined variables is presented in Appendix (Table A).

The results of hierarchical linear regression analyses with satisfaction with life as outcome variable are shown in Table 3. The control variables explained significant $7.1 \%$ of the variance in satisfaction with life, with romantic relationship as significant predictor. The BFI-2 factors explained added $34 \%$ of variance. The negative emotionality and open-mindedness were significant. The emerging adulthood dimensions factors added $5.68 \%$ of explained variance in satisfaction with life. In the final model, negative emotionality and open-mindedness (BFI-2) and stability and clarity of val-

Table 2 Correlations between predictors and outcomes variables

\begin{tabular}{lccc}
\hline & SWLS & MLQ-P & MLQ-S \\
\hline Emerging adulthood & & & \\
$\quad$ Stability & $\mathbf{0 . 5 6 2}$ & $\mathbf{0 . 5 0 7}$ & $\mathbf{- 0 . 1 8 6}$ \\
Self-focused orientation & $\mathbf{- 0 . 2 2 0}$ & $\mathbf{- 0 . 2 9 0}$ & 0.036 \\
Diffuse orientation & $\mathbf{- 0 . 2 8 9}$ & $-\mathbf{0 . 3 4 6}$ & 0.020 \\
Clarity of values & $\mathbf{0 . 4 7 5}$ & $\mathbf{0 . 7 1 0}$ & -0.035 \\
Identity exploration & $\mathbf{- 0 . 2 6 8}$ & $-\mathbf{0 . 4 1 4}$ & $\mathbf{0 . 4 1 3}$ \\
Concerns for others & 0.054 & 0.081 & 0.106 \\
Big Five & & & \\
Extraversion & $\mathbf{0 . 3 3 5}$ & $\mathbf{0 . 3 7 4}$ & -0.054 \\
Agreeableness & $\mathbf{0 . 3 9 0}$ & $\mathbf{0 . 3 7 0}$ & -0.034 \\
Conscientiousness & $\mathbf{0 . 3 7 9}$ & $\mathbf{0 . 3 6 1}$ & 0.001 \\
Negative emotionality & $\mathbf{- 0 . 5 5 5}$ & $\mathbf{- 0 . 4 5 3}$ & 0.146 \\
Open-mindedness & 0.198 & $\mathbf{0 . 2 2 7}$ & 0.119 \\
\hline
\end{tabular}

Note. SWLS - Satisfaction with life; MLQ-P - Presence of meaning; MLQ-S - Search for meaning. The correlations significant at $p<0.05$ are italicized, and $p<0.01$ are bolded. 
ues were significant predictors. The final model explained $46.9 \%\left(R^{2}=0.469 ; F_{(13 ; 224)}=12.22\right.$; $p<0.01$ ) of variance in satisfaction with life.

The results of hierarchical linear regression analyses with presence of meaning as outcome variable are shown in Table 4 . The control variables explained significant $8.45 \%$ of the variance in presence of meaning, with relationship status as significant predictor. The BFI-2 factors explained significant $26.2 \%$ of the added variance in presence of mean- ing, with negative emotionality, extraversion, agreeableness and open-mindedness being significant predictors. The emerging adulthood dimensions added $26.7 \%$ of explained variance. The final model explains $61.3 \%\left(R^{2}=\right.$ $\left.0.613 ; F_{(16: 222)}=21.99, p<0.01\right)$ of variance in presence of meaning, with stability, identity exploration and clarity of values as significant predictors.

Table 5 presents the results of hierarchical linear regression analyses with

Table 3 Results of hierarchical regression analysis predicting Satisfaction with life

\begin{tabular}{|c|c|c|c|c|c|c|}
\hline \multirow{4}{*}{ Predictors } & \multicolumn{6}{|c|}{ Outcome - Satisfaction with life } \\
\hline & \multicolumn{2}{|c|}{ Model 1} & \multicolumn{2}{|c|}{ Model 2} & \multicolumn{2}{|c|}{ Model 3} \\
\hline & & $95 \% \mathrm{Cl}$ & & $95 \% \mathrm{Cl}$ & & $95 \% \mathrm{Cl}$ \\
\hline & B & {$[\mathrm{LL} ; \mathrm{UL}]$} & B & [LL; UL] & B & [LL; UL] \\
\hline \multicolumn{7}{|l|}{ Block 1 - Control variables } \\
\hline Age & -0.022 & {$[-0.20 ; 0.16]$} & -0.058 & {$[-0.20 ; 0.09]$} & -0.072 & {$[-0.21 ; 0.07]$} \\
\hline Gender & -0.072 & {$[-0.43 ; 0.29]$} & -0.117 & {$[-0.41 ; 0.18]$} & -0.172 & {$[-0.46 ; 0.12]$} \\
\hline Educational level ( $2^{\text {nd }}$ vs. $\left.1^{\text {st }}\right)$ & 0.235 & {$[-0.17 ; 0.64]$} & 0.168 & {$[-0.16 ; 0.49]$} & 0.150 & {$[-0.17 ; 0.47]$} \\
\hline$\left(3^{\text {rd }}\right.$ vs. $\left.1^{\text {st }}\right)$ & 0.221 & {$[-0.64 ; 1.09]$} & 0.002 & {$[-0.70 ; 0.70]$} & -0.029 & {$[-0.71 ; 0.65]$} \\
\hline Relationship status & 0.471 & {$[0.22 ; 0.73]$} & 0.230 & {$[0.02 ; 0.44]$} & 0.190 & {$[-0.04 ; 0.42]$} \\
\hline \multicolumn{7}{|l|}{ Block 2 - Big Five } \\
\hline Extraversion & & & 0.037 & {$[-0.09 ; 0.16]$} & -0.010 & {$[-0.13 ; 0.11]$} \\
\hline Agreeableness & & & 0.137 & {$[0.02 ; 0.25]$} & 0.073 & {$[-0.05 ; 0.20]$} \\
\hline Conscientiousness & & & 0.126 & {$[0.01 ; 0.24]$} & 0.067 & {$[-0.07 ; 0.20]$} \\
\hline Negative emotionality & & & -0.424 & {$[-0.55 ;-0.30]$} & -0.242 & {$[-0.43 ;-0.06]$} \\
\hline Open-mindedness & & & 0.144 & {$[0.03 ; 0.26]$} & 0.123 & {$[0.01 ; 0.23]$} \\
\hline \multicolumn{7}{|l|}{ Block 3 - Emerging adulthood } \\
\hline Stability & & & & & 0.226 & {$[0.05 ; 0.40]$} \\
\hline Self-focused orientation & & & & & $<0.001$ & {$[-0.12 ; 0.12]$} \\
\hline Diffuse orientation & & & & & -0.011 & {$[-0.14 ; 0.12]$} \\
\hline Clarity of values & & & & & 0.214 & {$[0.09 ; 0.34]$} \\
\hline Identity exploration & & & & & 0.004 & {$[-0.11 ; 0.12]$} \\
\hline Concerns for others & & & & & 0.018 & {$[-0.09 ; 0.13]$} \\
\hline & \multirow{2}{*}{\multicolumn{2}{|c|}{$\begin{array}{c}R^{2}=0.071 \\
F(5 ; 232)=3.54\end{array}$}} & \multirow{2}{*}{\multicolumn{2}{|c|}{$\begin{array}{c}\Delta R^{2}=\mathbf{0 . 3 4 2} \\
\Delta F_{(5 ; 230)}=26.41\end{array}$}} & \multirow{2}{*}{\multicolumn{2}{|c|}{$\begin{array}{c}\Delta R^{2}=\mathbf{0 . 0 5 7} \\
\Delta \mathrm{F}_{(6 ; 224)}=\mathbf{3 . 9 4}\end{array}$}} \\
\hline & & & & & & \\
\hline
\end{tabular}

Note. $N=241$. The values in Model 1 represents results from the first block. The values after adding BFI-2 domains are presented in Model 2. Final results are presented in Model 3. The names of significant predictors in the final model are bolded. $\mathrm{Cl}=$ Confidence interval; $\mathrm{LL}=$ Lower limits; $\mathrm{UL}=$ Upper limit; $\Delta \mathrm{R}^{2}=$ change of $\mathrm{R}^{2} ; \Delta \mathrm{F}=$ change of $\mathrm{F}$. The values significant at $p<0.05$ are italicized, and $p<0.01$ are bolded. 
Table 4 Results of hierarchical regression analysis predicting Presence of meaning

\begin{tabular}{|c|c|c|c|c|c|c|}
\hline \multirow{4}{*}{ Predictors } & \multicolumn{6}{|c|}{ Outcome - Presence of meaning } \\
\hline & \multicolumn{2}{|c|}{ Model 1} & \multicolumn{2}{|c|}{ Model 2} & \multicolumn{2}{|c|}{ Model 3} \\
\hline & & $95 \% \mathrm{Cl}$ & & $95 \% \mathrm{Cl}$ & & $95 \% \mathrm{Cl}$ \\
\hline & b & {$[\mathrm{LL} ; \mathrm{UL}]$} & b & {$[\mathrm{LL} ; \mathrm{UL}]$} & b & {$[\mathrm{LL} ; \mathrm{UL}]$} \\
\hline \multicolumn{7}{|l|}{ Block 1 - Control factors } \\
\hline Age & -0.032 & {$[-0.20 ; 0.15]$} & -0.064 & {$[-0.22 ; 0.09]$} & -0.081 & {$[-0.20 ; 0.04]$} \\
\hline Gender & 0.038 & {$[-0.32 ; 0.39]$} & 0.046 & {$[-0.27 ; 0.36]$} & 0.016 & {$[-0.23 ; 0.26]$} \\
\hline Educational level ( $2^{\text {nd }}$ vs. $\left.1^{\text {st }}\right)$ & 0.358 & {$[-0.04 ; 0.75]$} & 0.294 & {$[-0.05 ; 0.63]$} & 0.247 & {$[-0.02 ; 0.52]$} \\
\hline ( $3^{\text {rd }}$ vs. $\left.1^{\text {st }}\right)$ & 0.693 & {$[-0.17 ; 1.55]$} & 0.418 & {$[-0.32 ; 1,16]$} & 0.277 & {$[-0.30 ; 0.86]$} \\
\hline Relationship status & 0.436 & {$[0.18 ; 0.69]$} & 0.245 & {$[0.02 ; 0.47]$} & 0.175 & {$[-0.02 ; 0.37]$} \\
\hline \multicolumn{7}{|l|}{ Block 2 - Big Five } \\
\hline Extraversion & & & 0.136 & {$[0.01 ; 0.26]$} & -0.002 & {$[-0.11 ; 0.10]$} \\
\hline Agreeableness & & & 0.165 & {$[0.04 ; 0.29]$} & 0.035 & {$[-0.07 ; 0.14]$} \\
\hline Conscientiousness & & & 0.105 & {$[-0.02 ; 0.23]$} & -0.011 & {$[-0.12 ; 0.10]$} \\
\hline Negative emotionality & & & -0.264 & {$[-0.39 ;-0.13]$} & -0.045 & {$[-0.20 ; 0.11]$} \\
\hline Open-mindedness & & & 0.126 & {$[0.01 ; 0.24]$} & 0.091 & {$[-<0.01 ; 0.19]$} \\
\hline \multicolumn{7}{|l|}{ Block 3 - Emerging adulthood } \\
\hline Stability & & & & & 0.179 & {$[0.03 ; 0.32]$} \\
\hline Self-focused orientation & & & & & -0.037 & {$[-0.14 ; 0.07]$} \\
\hline Diffuse orientation & & & & & 0.003 & {$[0.11 ; 0.12]$} \\
\hline Clarity of values & & & & & 0.529 & {$[0.42 ; 0.64]$} \\
\hline Identity exploration & & & & & -0.134 & {$[-0.23 ;-0.04]$} \\
\hline Concerns for others & & & & & 0.012 & {$[-0.08 ; 0.11]$} \\
\hline & \multirow{2}{*}{\multicolumn{2}{|c|}{$\begin{array}{c}R^{2}=\mathbf{0 . 0 8 5} \\
F_{(5 ; 233)}=\mathbf{4 . 3 0}\end{array}$}} & \multirow{2}{*}{\multicolumn{2}{|c|}{$\begin{array}{c}\Delta R^{2}=\mathbf{0 . 2 6 2} \\
\Delta F_{(5 ; 228)}=\mathbf{1 8 . 2}\end{array}$}} & \multirow{2}{*}{\multicolumn{2}{|c|}{$\begin{array}{c}\Delta R^{2}=0.267 \\
\Delta F_{(6 ; 222)}=25.5\end{array}$}} \\
\hline & & & & & & \\
\hline
\end{tabular}

Note. $N=241$. The values in Model 1 represents results from the first block. The values after adding BFI-2 domains are presented in Model 2. Final results are presented in Model 3. The names of significant predictors in the final model are bolded. $\mathrm{Cl}=$ Confidence interval; $\mathrm{LL}=$ Lower limits; $\mathrm{UL}=$ Upper limit; $\Delta \mathrm{R}^{2}=$ change of $\mathrm{R}^{2} ; \Delta \mathrm{F}=$ change of $\mathrm{F}$. The values significant at $p<0.05$ are italicized, and $p<0.01$ are bolded.

search for meaning as outcome variable. The control variables - age, gender, relationship status and educational level - as well as the BFI-2 factors were non-significant. The emerging adulthood dimensions explained $17.1 \%$ of the added variance in search for meaning. Only identity exploration was a significant predictor. The final model explains $22.8 \%\left(R^{2}=0.228 ; F_{(16 ; 220)}=\right.$ $4.07 ; p<0.01)$ of variance in search for meaning.

\section{Discussion}

The present study aimed to confirm the explaining power of Big Five personality traits for satisfaction with life and meaning in life and to find whether the characteristics of the emerging adulthood era explain the added variance.

In the first step, expected significant relationships of satisfaction with life (Tanksale, 
Table 5 Results of hierarchical regression analysis predicting Search for meaning

\begin{tabular}{|c|c|c|c|c|c|c|}
\hline \multirow{4}{*}{ Predictors } & \multicolumn{6}{|c|}{ Outcome - Search for meaning } \\
\hline & \multicolumn{2}{|c|}{ Model 1} & \multicolumn{2}{|c|}{ Model 2} & \multicolumn{2}{|c|}{ Model 3} \\
\hline & & $95 \% \mathrm{Cl}$ & & $95 \% \mathrm{Cl}$ & & $95 \% \mathrm{Cl}$ \\
\hline & 8 & {$[\mathrm{LL} ; \mathrm{UL}]$} & 8 & [LL; UL] & B & [LL; UL] \\
\hline \multicolumn{7}{|l|}{ Block 1 - Control factors } \\
\hline Age & -0.137 & {$[-0.32 ; 0.05]$} & -0.142 & {$[-0.33 ; 0.04]$} & -0.164 & {$[-0.33 ; 0.01]$} \\
\hline Gender & 0.269 & {$[-0.10 ; 0.64]$} & 0.268 & {$[-0.11 ; 0.65]$} & 0.339 & {$[-0.02 ; 0.69]$} \\
\hline Educational level ( $2^{\text {nd }}$ vs. $\left.1^{\text {st }}\right)$ & 0.297 & {$[-0.12 ; 0.71]$} & 0.344 & {$[-0.07 ; 0.76]$} & 0.356 & {$[-0.03 ; 0.74]$} \\
\hline$\left(3^{\text {rd }}\right.$ vs. $\left.1^{\text {st }}\right)$ & 0.240 & {$[0.65 ; 1.13]$} & 0.194 & {$[-0.69 ; 1.08]$} & 0.222 & {$[-0.60 ; 1.04]$} \\
\hline Relationship status & -0.042 & {$[-0.30 ; 0.22]$} & -0.005 & {$[-0.27 ; 0.26]$} & -0.014 & {$[-0.29 ; 0.26]$} \\
\hline \multicolumn{7}{|l|}{ Block 2 - Big Five } \\
\hline Extraversion & & & -0.033 & {$[-0.19 ; 0.12]$} & -0.014 & {$[-0.16 ; 0.13]$} \\
\hline Agreeableness & & & -0.002 & {$[-0.15 ; 0.15]$} & 0.012 & {$[-0.14 ; 0.16]$} \\
\hline Conscientiousness & & & 0.049 & {$[-0.10 ; 0.20]$} & 0.078 & {$[-0.09 ; 0.17]$} \\
\hline Negative emotionality & & & 0.161 & {$[<0.01 ; 0.32]$} & -0.095 & {$[-0.32 ; 0.13]$} \\
\hline Open-mindedness & & & 0.116 & {$[-0.03 ; 0.26]$} & 0.041 & {$[-0.09 ; 0.17]$} \\
\hline \multicolumn{7}{|l|}{ Block 3 - Emerging adulthood } \\
\hline Stability & & & & & -0.181 & {$[-0.39 ; 0.03]$} \\
\hline Self-focused orientation & & & & & -0.081 & {$[-0.23 ; 0.07]$} \\
\hline Diffuse orientation & & & & & 0.080 & {$[-0.08 ; 0.24]$} \\
\hline Clarity of values & & & & & 0.129 & {$[-0.03 ; 0.28]$} \\
\hline Identity exploration & & & & & 0.445 & {$[0.31 ; 0.58]$} \\
\hline Concerns for others & & & & & 0.027 & {$[-0.11 ; 0.16]$} \\
\hline & \multicolumn{2}{|c|}{$\begin{array}{c}R^{2}=0.018 \\
F_{(5 ; 231)}=0.84\end{array}$} & \multicolumn{2}{|c|}{$\begin{array}{c}\Delta R^{2}=0.039 \\
\Delta F_{(5 ; 226)}=1.88\end{array}$} & \multicolumn{2}{|c|}{$\begin{array}{c}\Delta R^{2}=0.171 \\
\Delta F_{(6 ; 220)}=8.15\end{array}$} \\
\hline
\end{tabular}

Note. $N=241$. The values in Model 1 represents results from the first block. The values after adding BFI-2 domains are presented in Model 2. Final results are presented in Model 3. The names of significant predictors in the final model are bolded. $\mathrm{Cl}=$ Confidence interval; $\mathrm{LL}=\mathrm{Lower}$ limits; $\mathrm{UL}=$ Upper limit; $\Delta \mathrm{R}^{2}=$ change of $\mathrm{R}^{2} ; \Delta \mathrm{F}=$ change of $\mathrm{F}$. The values significant at $p<0.05$ are italicized, and $p<0.01$ are bolded.

2015; Morris et al., 2015) and the presence of meaning (Francis \& Hills, 2008; Halama, 2005; Steger et al., 2006) were confirmed. Moreover, the study found relationships of satisfaction with life with agreeableness and open-mindedness, as well as a relationship of the presence of meaning with open-mindedness. The relationship of search for meaning with open-mindedness (Steger et al., 2006) was not confirmed; only a relationship between search for meaning and negative emotionality was found. It might have been caused by the fact that the previous studies were carried out on the general population which might have already had meaning in life and the individuals searched for additional meaning in other life areas (Steger et al., 2006). Further search for meaning might be more common for people with higher open-mindedness. On the other hand, emerging adults are in a prolonged identity moratorium (Wood et al., 2018), commonly linked with search for meaning (Hill et 
al., 2016). They might not search for additional meaning, but rather for "the essence of meaning". The absence of meaning and subsequent search for one might then be linked to higher negative emotionality.

All factors of the dimensions of emerging adulthood were related to satisfaction with life and presence of meaning. The strongest relationships were found with stability and clarity of values. These findings are in line with the previous research (Negru, 2012; Smojver-Ažić et al., 2017). As far as search for meaning is concerned, relationships were found with identity exploration, which is in line with Hill et al. (2016), and there was a negative relationship with stability and clarity of values, which is not surprising, as the search for life directions can bring some uncertainty.

One of the aims of the present study was met by confirming the prediction of satisfaction with life by Big Five personality traits and the emerging adulthood dimensions. Satisfaction with life was significantly predicted by the relationship status, however, it became insignificant in the final model. In line with the previous research (Kohút, Kohútová, Žitný et al., 2020), it was confirmed that Big Five personality traits predicted satisfaction with life. In the study, Big Five personality traits together explained $38 \%$ of the variance in satisfaction in life. In this model, negative emotionality and open-mindedness were the only significant predictors. As negative emotionality predisposes a person to anxiety, this might lead to lower levels of life satisfaction (Schimmack et al., 2004). On the contrary, having a wide range of cognitive or affective experiences (Soto \& John, 2017) might increase the level of satisfaction with life. The dimensions of emerging adulthood added $6.4 \%$ of added variance over Big Five personality traits. Apart from negative emotionality and open-mindedness, which remain significant, stability and clarity of values become significant in the fi- nal model. Although Big Five personality traits seem to be a strong predictor of satisfaction with life, the characteristics of emerging adulthood also play an important role. More stability and more clarified values can contribute to higher satisfaction in life. On the contrary, the time of emerging adulthood is characterized by less stability and less clarified values (Arnett, 2001) in comparison to other age groups (e.g., Macek et al., 2007; Reifman et al., 2007). Search for identity and important life values is prolonged by almost 10 years. As a consequence, the negative effects on satisfaction with life might last for a longer time. This result might differ for men, who are underrepresented in our sample. As they reach lower levels of psychological characteristics of emerging adulthood (Sirsch et al., 2009), the impact on satisfaction with life might differ. However, further research is needed.

To confirm the predictions of the presence of meaning, the model was controlled for demographic variables. The relationship status significantly predicted presence of meaning, however, it became insignificant in the final model. The Big Five personality traits explained $30.6 \%$ of the variance in presence of meaning. As for satisfaction with life, personality gives a base for the presence of meaning in life. All factors of Big Five personality traits but conscientiousness were significant for meaning in life. The dimensions of emerging adulthood explained added $28.1 \%$ of the variance in presence of meaning, and, after adding emerging adulthood dimensions to the model, only openness remains significant with a small effect size. In the final model, clarity of values and stability were significant in a positive way and identity exploration was significant in a negative way. As noted above, the instability, low clarity of values and identity exploration are common for university students (Arnett, 2001, 2018). The clarity of values was the most important predictor of the presence 
of meaning, which is in line with the theoretical assumption, since the clarification of values helps to find direction of life and meaning (Hill et al., 2016). Findings of the present study suggest that the presence of meaning, which is also important for a satisfying life (García-Alandete, 2015), could be limited in emerging adulthood time. Our results might slightly differ for men, who report lower levels of characteristics of emerging adulthood compared to women (Sirsch et al., 2009), especially in identity experimentation (Negru, 2012). Thus, future research is needed.

Contrary to satisfaction with life and the presence of meaning, search for meaning was not significantly predicted by Big Five personality traits. A similar pattern of non-stable and weak correlations, especially with negative emotionality or open-mindedness and with the search for meaning, was found in previous studies (Halama, Martos, \& Adamovová, 2010; Newman, Nezlek, \& Thrash, 2018; Halama et al., 2020; Kohút, Halama, Soto et al., 2020). The reason for this might be that search for meaning is conceptualized as reconciling discrepancies between global meaning as a trait and situational meaning. In the search for meaning, the stable trait of continually trying to search for meaning might be combined with daily state of trying to find the meaning in life events (Newman, Nezlek, \& Thrash, 2017). The dimensions of emerging adulthood explained $17 \%$ of the added variance. The only significant predictor was the identity exploration, which was expected, since the search for meaning and search for identity are interconnected (Hill et al., 2016). Identity exploration is one of the developmental tasks in the time of growing up (Arnett, 2019). The search for meaning takes place when the person has low meaning, as may be the case during adolescence and emerging adulthood, as well as when the meaning in life is present (Steger, 2006). However, the results suggest, that the search for meaning can be notable in emerging adulthood, since the search for oneself also predicts the search for life goals and meaning in life.

Emerging adulthood is a long period of searching and instability but also of great freedom and possibilities (Arnett, 2000) that are unlikely to be ever present again. On the other hand, these possibilities and gained freedom together with a lack of rules and norms (Côte, 2014) bring instability and uncertainty, raising questions which life direction is the best, what is important for individuals, and what they should do in their lives. Postponing these important tasks almost until the age of 30 could have negative consequences for the presence of meaning and satisfaction with life for a longer time. This may result in an increased need for support and help from a university.

\section{Limitations and Further Directions}

The present study brings a new perspective on the importance of understanding meaning in life and satisfaction with life in the context of emerging adulthood. The generalization of our results is limited by the small sample and the higher prevalence of women. Also, low internal consistency of Concerns for others domain might be the reason for the lack of correlations with this variable. In the future, a cross-cultural comparison of the impact of emerging adulthood on satisfaction with life and meaning in life might bring additional understanding. In addition, possible differences in the effects of emerging adulthood dimensions among emerging adults with and without a partner or with and without work experience would give a deeper insight.

\section{Conclusions}

The findings of the present study confirm the importance of Big Five personality traits and 
characteristics of emerging adulthood for satisfaction in life and the presence of meaning. Moreover, the findings suggest that characteristics of emerging adulthood, in particular instability, low clarity of values, and identity exploration can be important for satisfaction with life and meaning in life.

\section{Acknowledgment}

This study has been funded by project Vega Cognitive-existential profile and post-traumatic growth in cancer survivors (No. 1/0305/18).

\section{Authors' ORCID \\ Veronika Kohútová \\ https://orcid.org/0000-0002-9888-4275 \\ Marián Špajdel \\ https://orcid.org/0000-0002-5995-3741 \\ Mária Dědová \\ https://orcid.org/0000-0002-8960-6142}

\section{References}

Arnett, J. J. (2000). Emerging adulthood. A theory of development from the late teens through the twenties. American Psychologist, 55(5), 469-480. https://doi.org/10.1037//0003-066X.55.5.469

Arnett, J. J. (2018). Adolescence and emerging adulthood: A cultural approach (6th edition). Pearson.

Arnett, J. J. (2004). The winding road from the late teens through twenties. Oxford University Press.

Arnett, J. J. (2019). Conceptual foundations of emerging adulthood. In J. L. Murray \& J. J. Arnett (Eds.), Emerging adulthood and higher education: A new student development paradigm (pp. 11-25). Routledge.

Arnett, J. J. (2001). Conceptions of the transition to adulthood: Perspectives from adolescence through midlife. Journal of Adult Development, 8(2), 133143. https://doi.org/10.1023/A:1026450103225

Côté, J. E. (2014). The dangerous myth of emerging adulthood: An evidence-based critique of a flawed developmental theory. Applied Developmental Science, 18(4), 177-188. https://doi.org $\not 10.1080 / 10888691.2014 .954451$
Crocetti, E., Tagliabue, S., Sugimura, K., Nelson, L. J., Takahashi, A., Niwa, T., Sugiura, Y., \& Jinno, M. (2015). Perceptions of emerging adulthood: A study with Italian and Japanese university students and young workers. Emerging Adulthood, 3(4), 229243. https://doi.org/10.1177/2167696815569848

Dezutter, J., Waterman, A. S., Schwartz, S. J., Luyckx, K., Beyers, W., Meca, A., Kim, S. Y., Whitbourne, S. K., Zamboanga, B. L., Lee, R. M., Hardy, S. A., Forthun, L. F., Ritchie R. A., Weisskirch, R. S., Brown, E. J., \& Caraway, S. J. (2014). Meaning in life in emerging adulthood: A person-oriented approach. Journal of Personality, 82(1), 57-68. https://doi.org/10.1111/jopy.12033

Diener, E., Emmons, R. A., Larsen, R. J., \& Griffin, S. (1985). The Satisfaction with Life Scale. Journal of Personality Assessment, 49(1), 71-75. https:// doi.org/10.1207/s15327752ipa4901 13

Diener, E., Suh, E. M., Lucas, R. E., \& Smith, H. L. (1999). Subjective well-being: Three decades of progress. Psychological Bulletin, 125(2), 276-302. https://doi.org/10.1037/0033-2909.125.2.276

Dodge, R., Daly, A. P., Huyton, J., \& Sanders, L. D. (2012). The challenge of defining well-being. International Journal of Well-being, 2(3), 222235. https://doi.org./10.5502/ijw.v2i3.4

Džambazovič, R. (2018). Neskorá mladost'. Nový generačný model prechodu do dospelosti a jeho príčiny. In B. Balogová \& M. Hamadej (Eds.), Aktuálne oblasti spoločenského výskumu (pp.1729). Prešovská univerzita.

Faul, F., Erdfelder, E., Buchner, A., \& Lang, A.-G. (2009). Statistical power analyses using G*Power 3.1: Tests for correlation and regression analyses. Behavior Research Methods, 41(4), 11491160. https://doi.org/10.3758/BRM.41.4.1149

Francis, L. J., \& Hills, P. R. (2008). The development of the Meaning in Life Index (MILI) and its relationship with personality and religious behaviours and beliefs among UK undergraduate students. Mental Health, Religion and Culture, 11(2), 211-220. https://doi. org/10.1080/13674670701243758

García-Alandete, J. (2015). Does meaning in life predict psychological well-being? An analysis using the Spanish versions of the Purpose-In-Life Test and the Ryff's Scales. The European Journal of Counselling Psychology, 3(2), 89-98. https:// doi.org/10.5964/ejcop.v3i2.27 
Glanzer, P. L., Hill, J. P., \& Robinson, J. A. (2015). Emerging adults' conceptions of purpose and the good life: A classification and comparison. Youth and Society, 50(6), 715-733. https://doi. org/10.1177/0044118X15602918

Halama, P. (2005). Relationship between meaning in life and the Big Five personality traits in young adults and the elderly. Studia Psychologica, 47(3), 167-178.

Halama, P., Kohút, M., Soto, C. J., \& John, O. P. (2020). Slovak adaptation of the Big Five Inventory (BFI-2): Psychometric properties and initial validation. Studia Psychologica, 62(1), 74-87. https://doi.org/10.31577/sp.2020.01.792

Halama, P., Martos, T., \& Adamovová, L. (2010). Religiosity and well-being in Slovak and Hungarian student samples: The role of personality traits. Studia Psychologica, 52(2), 101-115.

Hill, P. L., Edmonds, G. W., Peterson, M., Luyckx, K., \& Andrews, J. A. (2016). Purpose in life in emerging adulthood: Development and validation of a new brief measure. Journal of Positive Psychology, 11(3), 237-245. https://doi.org/10.1080/174 $\underline{39760.2015 .1048817}$

Huber, E., \& Stephens, J. D. (1993). Political parties and public pensions: A quantitative analysis. Acta Sociologica, 36(4), 309-325. https://doi. org $/ 10.1177 / 000169939303600401$

The Jamovi project (2020). Jamovi (Version 1.2). [Computer Software]. https://www.jamovi.org/

Karaś, D., Cieciuch, J., Negru, O., \& Crocetti, E. (2014). Relationships between identity and well-being in Italian, Polish, and Romanian emerging adults. Social Indicators Research, 121(3), 727-743. https://doi.org/10.1007/s11205-014-0668-9

Kohút, M., Kohútová, V., Žitný, P., \& Halama, P. (2020). Further validation of Slovak Big Five Inventory 2: 6-months test-retest stability and predictive power. Studia Psychologica, 62(3), 246258. https://doi.org/10.31577/sp.2020.03.802

Kohút, M., Halama, P., Soto, C. J., \& John, O. P. (2020). Psychometric properties of Slovak short and extra-short forms of Big Five Inventory - 2 (BFI-2). Československá Psychologie, 64(5), 550563.

Kohútová, V., \& Dědová, M. (2019). Nerovná cesta do dospelosti: Špecifiká obdobia vynárajúcej sa dospelosti v kontexte identity, práce a partnerských vztáahov. Psychológia a Patopsychológia
Dietatá, 53(2), 89-102. https://doi.org/10.4149/ ppd 201907

Lane, J. A., Leibert, T. W., \& Goka-Dubose, E. (2017). The impact of life transition on emerging adult attachment, social support, and well-being: A multiple-group comparison. Journal of Counseling and Development, 95(4), 378-388. https://doi.org/10.13140/RG.2.2.14075.11043

Macek, P., Bejček, J., \& Vaníčková, J. (2007). Contemporary Czech emerging adults: Generation growing up in the period of social changes. Journal of Adolescent Research, 22(5), 444-475. https://doi.org/10.1177/0743558407305417

Morris, M. B., Burns, G. N., Periard, D. A., \& Shoda, E. A. (2015). Extraversion-emotional stability circumplex traits and subjective well-being. Journal of Happiness Studies, 16(6), 1509-1523. https:// doi.org/10.1007/s10902-014-9573-9

Negru, O. (2012). The time of your life. Emerging adulthood characteristics in a sample of Romanian high-school and university students. Cognition, Brain, Behavior: An Interdisciplinary Journal, 16(3), 357-367.

Newman, D. B., Nezlek, J. B., \& Thrash, T. M. (2018). The dynamics of searching for meaning and presence of meaning in daily life. Journal of Personality, 86(3), 368-379. https://doi. org/10.1111/iopy.12321

Oleskowicz, A., \& Misztela, A. (2015). How do young Poles perceive their adulthood? Journal of Adolescent Research, 30(6), 683-709. https:// doi.org/10.1177/0743558415569727

Pace, U., Cacioppo, M., Lo Cascio, V., Guzzo, G., \& Passanisi, A. (2016). Are there similar or divergent transitions to adulthood in a Mediterranean context? A Cross-national comparison of Italy and Spain. Europe's Journal of Psychology, 12(1), 153-168. https://doi.org/10.5964/ejop. v12i1.1043

Pan, Y., \& Jackson, R. T. (2008). Ethnic difference in the relationship between acute inflammation and serum ferritin in US adult males. Epidemiology and Infection, 136(3), 421-431. https://doi. org/10.1017/S095026880700831X

Park, C. L. (2010). Making sense of the meaning literature: An integrative review of meaning making and its effects on adjustment to stressful life Events. Psychological Bulletin, 136(2), 257-301. https://doi.org/10.1037/a0018301 
Piotrowski, K., Brzezińska, A. I., \& Luyckx, K. (2018). Adult roles as predictors of adult identity and identity commitment in Polish emerging adults: Psychosocial maturity as an Intervening variable. Current Psychology, 39, 2149-2158. https://doi. org/10.1007/s12144-018-9903-x

Quevedo, R. J. M., \& Abella, M. C. (2011). Well-being and personality. Facet-level analyses. Personality and Individual Differences, 50(2), 206-211. https://doi.org/10.1016/J.PAID.2010.09.030

Reifman, A., Arnett, J. J., \& Colwell, M. J. (2007) Emerging adulthood: Theory, assessment and application. Journal of Youth Development, 2(1), 1-12. https://doi.org/10.5195/JYD.2007.359

Roupa, M. (2016). Čo to znamená byt' dospelý podla slovenských vysokoškolských študentov. Acta Geographica Universitatis Comenianae, 60(1), 37-68.

Ryan, R. M., \& Deci, E. L. (2001). On happiness and human potentials: A review of research on hedonic and eudaimonic well-being. Annual Review of Psychology, 52, 141-166. https://doi. org/10.1146/annurev.psych.52.1.141

Ryff, C. D., \& Singer, B. (1998). The contours of positive human health. Psychological Inquiry, 9(1), 1-28. https://doi.org/10.1207/s15327965pli0901 1

Samman, E. (2007). Psychological and subjective well-being: A proposal for internationally comparable indicators. Oxford Development Studies, 35(4), 459486. https://doi.org/10.1080/13600810701701939

Schimmack, U., Oishi, S., Furr, R. M., \& Funder, D. C. (2004). Personality and life satisfaction: A facet-level analysis. Personality and Social Psychology Bulletin, 30(8), 1062-1075. https://doi. org/10.1177/0146167204264292

Schnell, T., \& Becker, P. (2006). Personality and meaning in life. Personality and Individual Differences, 41(1), 117-129. https://doi.org/10.1016/i. paid.2005.11.030

Schwartz, J., Tanner, J. L., \& Syed, M. (2016). Emerging adulthood. In The Encyclopedia of Adulthood and Aging. John Wiley \& Sons. https://doi. org/10.1002/9781118521373.wbeaa263

Sirsch, U., Dreher, E, Mayr, E., \& Willinger, U. (2009). What does it take to be an adult in Austria?: Views of adulthood in Austrian adolescents, emerging adults, and adults. Journal of Adolescent Research, 24(3), 275-292. https:// doi.org/10.1177/0743558408331184
Smojver-Ažić, S., Martinac-Dorčić, T., \& Živčić- Bećirević, I. (2017, August 29 - September 1). Life satisfaction and dimensions of emerging adulthood in regards to professional status [Poster presentation]. 18th European Conference on Developmental Psychology, Utrecht.

Soto, C. J., \& John, O. (2017). The next Big Five Inventory (BFI-2): Developing and assessing a hierarchical model with 15 facets to enhance bandwidth, fidelity, and predictive power. Journal of Personality and Social Psychology, 113(1), 117143. https://doi.org/10.1037/pspp0000096

Steger, M. F., \& Frazier, P. (2005). Meaning in life: One link in the chain from religiousness to well-being. Journal of Counseling Psychology, 52(4), 574-582. https://doi.org/10.1037/00220167.52.4.574

Steger, M. F., Oishi, S., \& Kashdan, T. B. (2009). Meaning in life across the life span: Levels and correlates of meaning in life from emerging adulthood to older adulthood. The Journal of Positive Psychology, 4(1), 43-52. https://doi. org/10.1080/17439760802303127

Steger, M. F., Kashdan, T. B., Sullivan, B. A., \& Lorentz, D. (2008). Understanding the search for meaning in life: Personality, cognitive style, and the dynamic between seeking and experiencing meaning. Journal of Personality, 76(2), 199-228. https:// doi.org/10.1111/i.1467-6494.2007.00484.x

Steger, M. F., Frazier, P., Oishi, S., \& Kaler, M. (2006). The Meaning in Life Questionnaire: Assessing the presence of and search for meaning in life. Journal of Counseling Psychology, 53(1), 80-93. https://doi.org/10.1037/0022-0167.53.1.80

Sumner, R., Burrow, A. L., \& Hill, P. L. (2014). Identity and purpose as predictors of subjective well-being in emerging adulthood. Emerging Adulthood, 3(1), 4654. https://doi.org/10.1177/2167696814532796

Šprocha, B. (2018). Prechody do dospelosti na Slovensku v priestorovej perspektíve podla sčítania obyvatel'stva 1991 a 2011. Geographical Journal, 70(2), 117-140. https://doi.org/10.31577/ geogrcas.2018.70.2.07

Štatistický úrad Slovenskej republiky (2021). Obyvatel'stvo a migrácia. Pramenné diela Sobáše. https://slovak.statistics.sk/wps/portal/ ext/themes/demography/population/indicators/!ut/p/z1/IZFBD4IwDIV 0joYDI4DZUwlwhDBXgwnQ6Lowfj7nYSTxqG9NX1f8 pKkHQEx 4x- 
nPr7cB37s-kP6B8rroloogKCaO-A4oWmWVXJjDLSvgkKvQa1E6XUG0aBeQTNOKILR4RMxiu9Tcw4dol69x0AOvMWgY2X szHUqSM5WBBLi1QIm10WLkuCHfiF 3DlxLwG28xiP 19yFAu72W4CSxJbC0A5eehNYrGr6wwaRwuzSv6mBQwxNgeB7i/dz/ d5/L2dJQSEvUUt3QS80TmxFL102X1E3SThCQjFBMDhCVjIwSTdOUjFLUVFHSTky/

Tanksale, D. (2015). Big Five personality traits: Are they really important for the subjective well- being of Indians? International Journal of Psychology, 50(1), 64-69. https://doi.org/10.1002/ ijop.12060

Wood, D., Crapnell, T., Lau, L., Bennett, A., Lotstein, D., Ferris, M., \& Kuo, A. (2018). Emerging adulthood as a critical stage in the life course. In N. Halfon, C. Forrest, R. Lerner, \& E. Faustman (Eds.), Handbook of Life Course Health Development (pp.123-143). Springer.

\section{Appendix}

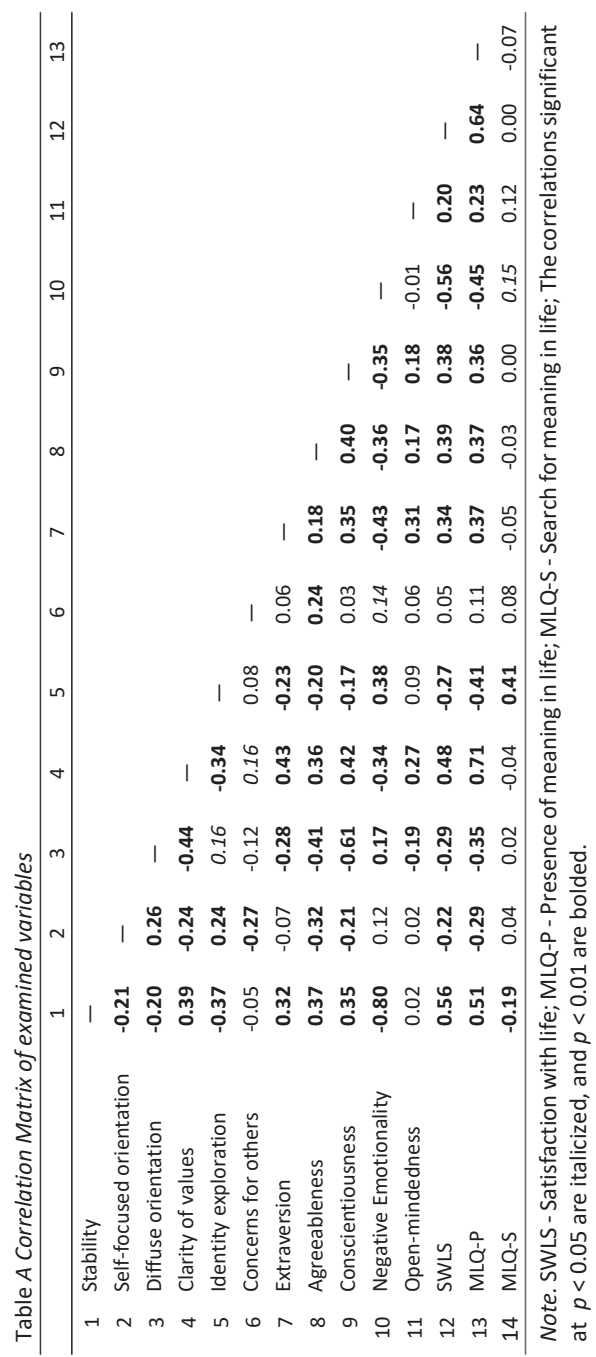

